\title{
SPECIFICATION FOR \\ 20,000 GALLON \\ LIQUID ARGON STORAGE TANK
}

\author{
D-ZERO PROJECT \\ FERM ILAB
}

G. T. MULHOLLAND

G. STEPANEK

DECEMBER 1985

REV A 
1.0 SCOPE

$1 . \overline{1}$ THIS SPECIFICATION DEFINES THE REQUIREMENTS FOR A LIQUID NITROGEN EQUIPPED, LIQUID ARGON STORAGE TANR TO BE INSTALLED AT FERMILAB, BATAVIA, ILLINOIS.

2.0 TANR DATA

2.1 P \& I DIAGRAM -

2.2 CONFIGURATION - 10 FT DIA, HORIZ

2.3 CAPACITY

2.3.1 WATER VOLUME - 20,000 GALLONS

2.3.2 LIQUID ARGON VOLUME AT TRYCOCK --- 19,000 GALLONS

2.4 MAX IMUM ALLOWABLE WORR ING PRESSURE ---- 65 PSIG, VACUUM

2.5 MINIMUM ALLOWABLE TEMPERATURE - -

2.6 REQUIRED DISCHARGE CAPACITY

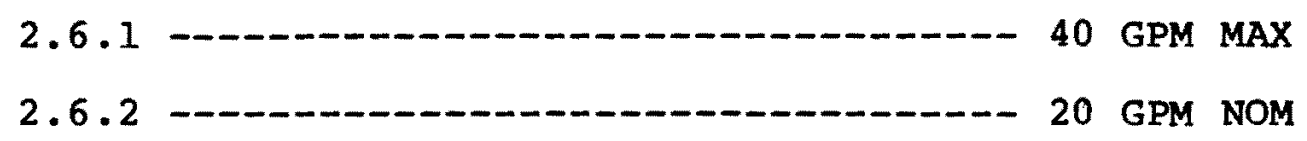

2.7 MINIMUM CONDENSER CAPACITY AT 5 PSIG,

80 DEG KELVIN NITROGEN.-

2.8 REQUIRED TANK OPERATING PRESSURE------- 30 PSIG

2.9 OPERATION -

2. 10 FILLING

2.10.1 - - - FROM COMMERCIAL HIGHWAY TRANSPORT

2.11 NORMAL EVAPORATION RATE - - - NOT TO EXCEED 0.308 OF CAPACITY PER DAY AT 50 MILLITORR VACUUM

2.12 MOUNTING ---- TWO SADDLES OR FOUR LEGS, WITH PROVISION FOR ANCHOR BOLTS, FOR INSTALLATION ON BUYERS CONCRETE PIERS.

2.13 HANDLING PROVISIONS --- LIFTING LUGS TO PERMIT LIFTING TANK INTO PLACE. ANY SPECIAL SPREADER BARS REQUIRED SHALL BE FURNISHED WITH TANK.

2.14 PAINT -- - ALL EXTERIOR CARBON STEEL SURFACES TO BE SUITABLY PRIMED AND FINISHED WITH WHITE POLYURETHANE ENAMEL - DUPONT IMRON OR EQUAL. 
3.0 TANK DESIGN

3.1 TANR SHALL BE CONVENTIONAL DOUBLE-WALL CRYOGENIC TANK WITH EVACUATED PERLITE INSULATION.

3.2 INNER VESSEL SHALL BE BUILT AND STAMPED IN ACCORDANCE WITH THE ASME PRESSURE VESSEL CODE, SECTION VIII, DIVISION 1, FOR THE M.A.W.P. IN 2.4 ABOVE, AND M.A.T. IN 2.5 ABOVE, AND SHALL BE REGISTERED WITH THE NATIONAL BOARD.

3.3 OUTER VESSEL (VACUUM JACKET) SHALL BE OF STEEL, DESIGNED FOR FULL VACUUM INTERNAL WITH A SAFETY FACTOR NOT LESS THAN TWO (MINIMUM COLLAPSE PRESSURE OF 30 PSI).

3.4 PIPING

3.4.1 PIPING CONNECTING TO THE INNER VESSEL IN THE VACUUM SPACE SHALL BE OF WELDABLE 300 SERIES STAINLESS STEEL, AND SHALL BE FORMED FROM CONTINUOUS LENGTHS OF PIPE OR TUBING TO THE MAXIMUM EXTENT PRACTICAL. JOINTS SHALL BE WELDED.

3.4.2 ARGON PIPING OUTSIDE THE OUTER VESSEL SHALL BE COPPER, COPPER ALLOYS OR STAINLESS STEEL SUITABLE FOR CRYOGENIC SERVICE. COPPER FITTINGS SHALL BE WROUGHT OR BAR STOCK SOLDER JOINT TYPE. STAINLESS FITTINGS SHALL BE WELD TYPE. VACUUM JACKETED PIPING SHALL BE STAINLESS STEEL.

3.4.3 GAGE CONNECTIONS AND SAFETY DEVICE CONNECTIONS SHALL BE THREADED AND MADE UP WITH OXYGEN-COMPATIBLE THREAD SEALANT. OTHER JOINTS SHALL BE SILVER-BRAZED FOR COPPER OR COPPER ALLOYS, OR WELDED FOR STAINLESS STEEL.

3.4.4 PIPING CONNECTED TO THE INNER VESSEL SHALL INCLUDE

3.4.4.1 TOP BAYONET ENTRY, JACKETED TRANSPORT FILL LINE, CONNECTING TO VAPOR PHASE HAVING A SPLASH PLATE OR SPRAY HEADER INSIDE INNER VESSEL.

3.4.4.2 VENT AND SAFETY RELIEF LINE, CONNECTING TO VAPOR PHASE.

3.4.4.3 PRESSURE BUILD LIQUID FEED LINE AS CLOSE AS POSSIBLE TO THE BOTTOM.

3 4.4.4 PRESSURE BUILD VAPOR RETURN LINE, CONNECECTING TO VAPOR PHASE.

3.4.4.5 JACKETED LIQUID DELIVERY LINE, CONNECTING TO LIQUID PHASE AS CLOSE AS POSSIBLE TO THE BOTTOM. 
3.4.4.6 FULL TRYCOCK LINE, HAVING ITS OPENING AT THE 19,000 GALLON LEVEL.

3.4.4.7 JACKETED CONDENSER ENTRY LINE

3.4.4.8 JACKETED CONDENSER EXIT LINE

3.4.4.9 TOP GAGE LINE, CONNECTING TO THE VAPOR PHASE.

3.4.4.10 BOTTOM GAGE LINE, CONNECTING TO LIQUID PHASE AS CLOSE AS POSSIBLE TO THE BOTTOM.

3.4.4.11 JACKETED GAS RETURN LINE CONNECTING TO THE VAPOR PHASE.

3.4 .5 VALVES

3.4.5.1 ALL VALVES SHALL BE SUITABLE FOR THEIR APPLICATION.

3.4.5.2 ALL COLD VALVES SHALL HAVE EXTENDED STEMS AND BONNETS.

3.4.5.3 PNEUMATIC ACTUATORS AND POSITIONERS (FISCHER) SHALL BE SUPPLIED AS INDICATED ON THE SCHEMATIC.

3.5 FILL LINE

3.5.1 THE LINE OF 3.4.4.1 SHALL BE EQUIPPED WITH A FULL LINE SIZE VACUUM-JACKETED VALVE AND BAYONET ASSEMBLY.

3.5.1.1 THE BAYONET AND VALVE ASSEMBLY SHALL BE CRYOLAB $11 / 2 "$, DWG CV1299, TO MATE WITH PUCHASER'S V-J DISTRIBUTION PIPING.

3.5.2 THE VACUUM SYSTEM OF THE VALVE AND BAYONET ASSEMBLY SHALL BE SEPARATE FROM THE TANK VACUUM SYSTEM.

3.6 LIQUID DELIVERY LINE

3.6.1 THE LINE OF 3.4.4.5 SHALL BE EQUIPPED WITH A FULL LINE SIZE VACUUM-JACKETED VALVE AND BAYONET ASSEMBLY

3.6.1.1 THE BAYONET AND VALVE ASSEMBLY SHALL BE CRYO-33333 LAB 1 1/2", DWG CV1299, TO MATE WITH PURCHASER'S V-J DISTRIBUTION PIPING.

3.6.2 THE VACUUM SYSTEM OF THE VALVE AND BAYONET ASSEMBLY SHALL BE SEPERATE FROM THE TANK VACUUM SYSTEM.

3.7 CONDENSER LINE

3.7.1 THE LINE OF 3.4.4.7-8 SHALL BE EQUIPPED WITH A FULL LINE SIZE VACUUM-JACKETED VALVE AND BAYONET ASSEMBLY

3.7.1.1 THE BAYONET AND VALVE ASSEMBLY SHALL BE CRYOLAB 1 1/2", DWG CV1299, TO MATE WITH PURCHASER'S V-J DISTRIBUTION PIPING. 
3.7.2 THE VACUUM SYSTEM OF THE VALVE AND BAYONET ASSEMBLY SHALL BE SEPERATE FROM THE TANR VACUUM SYSTEM.

3.8 JACKETED GAS RETURN LINE

3.8.1 THE LINE OF 3.4.4.11 SHALL BE EQUIPPED WITH A FULL LINE SIZE VACUUM-JACKETED VALVE AND BAYONET ASSEMBLY

3.8.1.1 THE BAYONET AND VALVE ASSEMBLY SHALL BE CRYOLAB 1 1/2", DWG CV1299, TO MATE WITH PURCHASER'S V-J DISTRIBUTION PIPING.

3.8.2 THE VACUUM SYSTEM OF THE VALVE AND BAYONET ASSEMBLY SHALL BE SEPERATE FROM THE TANK VACUUM SYSTEM.

3.9 SAFETY DEVICES

3.9.1 THE INNER VESSEL SHALL BE PROTECTED FROM EXCESSIVE INTERNAL PRESSURE BY A SYSTEM OF TWO SAFETY RELIEF VALVES, TWO RUPTURE DISCS, AND A EXTENDED STEM SELECTOR VALVE WITH ONE SAFETY RELIEF VALVE, AND ONE RUPTURE DISC ON EACH OUTLET OF THE SELECTOR VALVE.

3.9.1.1 THE SELECTOR VALVE SHALL BE SUCH THAT AT LEAST ONE OUTLET IS ALWAYS OPEN TO THE INNER VESSEL.

3.9.1.2 THE CAPACITIES OF EACH SAFETY RELIEF VALVE AND EACH RUPTURE DISC SHALL BE AS REQUIRED BY COMPRESSED GAS ASSOCIATION PAMPHLET S-1.3, OR 2" WHICHEVER IS LARGER.

3.9.2 THE OUTER VESSEL SHALL BE PROTECTED BY RELIEF DEVICES HAVING A DISCHARGE AREA OF AT LEAST 50 SQUARE INCHES AND OPENING AT A PRESSURE NOT MORE THAN THE LESSER OF THE INTERNAL DESIGN OF THE OUTER VESSEL ( AS CALCULATED BY THE ASME CODE) OR 15 PSIG.

3.9.3 ALL PIPING SECTIONS IN WHICH LIQUID NITROGEN OR ARGON OR VERY COLD GASEOUS NITROGEN OR ARGON COULD BE TRAPPED BY MANUAL OR AUTOMATIC CLOSING OF VALVES SHALL BE PROTECTED BY SUITABLE SAFETY RELIEF VALVES.

3.10 GASES

3.10.1 THE TANK SHALL BE PROVIDED WITH A DIFFERENTIAL PRESSURE LIQUID LEVEL GAGE, CONNECTED BETWEEN THE TOP AND BOTTOM GAGE LINES $(3.4 .4 .9$ AND 3.4 .4 .10 ABOVE). TWO SHUT-OFF VALVES AND A BY-PASS VALVE SHALL BE PROVIDED.

3.10.2 THE TANK SHALL BE PROVIDED WITH A PRESSURE GAGE, CONNECTED TO THE TOP GAGE LINE (3.4.4.9 ABOVE).

3.10.3 THE TANK SHALL BE PROVIDED WITH A HASTINGS THERMOCOUPLE VACUUM GAGE SENSING TUBE, CONNECTED TO THE VACUUM SPACE THROUGH A SUITABLE VALVE AND PERLITE FILTER. 


\subsubsection{A BATTERY-POWERED PORTABLE THERMOCOUPLE VACUUM} GAGE READ-OUT SHALL BE PROVIDED FOR THE TANK.

\subsection{PRESSURE BUILDING SYSTEM}

3.11.1 THE TANK SHALL BE PROVIDED WITH A PRESSURE BUILD-UP SYSTEM, COMPLETE WITH AMBIENT AIR HEATED VAPORIZING HEAT EXCHANGER.

3.11.2 THIS SYSTEM SHALL INCLUDE A LIQUID SUPPLY LINE WITH SHUT-OFF VALVE (MAY BE BRANCHED OFF BOTTOM FILL LINE); A VAPOR RETURN LINE (3.4.4.4) WITH SHUT-OFF VALVE; A PNEUMATIC REGULATING VALVE; NECESSARY PIPING SAFETY VALVES (3.8.3); IF HEAT EXCHANGER IS SHIPPED LOOSE, FLANGES FOR FIELD CONNECTIONS TO AND FROM HEAT EXCHANGER.

3.10.3 THIS SYSTEM SHALL BE SIZED TO MAINTAIN TANK PRESSURE PER 2.8 WHILE LIQUID ARGON IS DELIVERED PER 2.6 SO LONG AS THE LIQUID ARGON DEPTH IS TWO FEET OR MORE.

3.10.4 THE LOCATION OF THE PRESSURE BUILDING SYSTEM RELATIVE TO THE STORAGE TANK WILL BE AGREED UPON AT THE TIME OF CONTRACT AWARD.

4.0 TESTING AND DOCUMENTATION

IN ADDITION TO TESTING REQUIRED BY THE ASME CODE

4.1 THE TANK SHALL BE HELIUM MASS-SPECTROMETER (1SE-8 STD CC/SEC) TESTED FOR VACUUM-TIGHTNESS OF INNER AND OUTER VESSELS.

4.2 PIPING SHALL BE TESTED AT $90 \%$ OF M.A.W.P. AND ALL JOINTS, INCLUDING SAFETY DEVICE INLET CONNECTIONS, SHALL BE SOAP BUBBLE CHECKED FOR LEAKAGE.

4.3 THE MANUFACTURER SHALL FURNISH TO THE BUYER THE CODE UI-A FORM AND CERTIFICATE(S) OF MASS SPRECTOMETER AND PIPING TESTS.

\subsection{WARRANTY}

5.1 VACUUM: VACUUM NOT TO EXCEED 200 MICRONS COLD 12 MONTHS AFTER START-UP OR 18 MONTHS AFTER SHIPMENT, WHICHEVER COMES FIRST.

5.2 GENERAL: MANUFACTURER TO WARRANT MATERIAL AND WORKMANSHIP FOR A PERIOD OF ONE YEAR FROM START-UP OR 18 MONTHS FROM SHIPMENT, WHICHEVER COMES FIRST. 